\title{
Etika Melayani Pasien Muslim pada Stadium Terminal
}

Hadjat S Digdowirogo ${ }^{\mathrm{I}}$, Darmawan Budi Setyanto ${ }^{\mathrm{I}, 2}$, Pukovisa Prawiroharjo ${ }^{\mathrm{T}, 3}$

${ }^{1}$ Majelis Kehormatan Etik Kedokteran Pengurus Besar Ikatan Dokter Indonesia

${ }_{2}^{2}$ Departemen Ilmu Kesehatan Anak, Fakultas Kedokteran Universitas Indonesia/Rumah Sakit Cipto Mangunkusumo, Jakarta

${ }^{3}$ Departemen Neurologi, Fakultas Kedokteran Universitas Indonesia/Rumah Sakit Cipto Mangunkusumo, Jakarta

\author{
Kata Kunci \\ etika, Islam, kematian, Muslim, talkin, \\ terminal \\ Korespondensi \\ pukovisa@ui.ac.id \\ Publikasi \\ (C) 2019 JEKI/ilmiah.id \\ DOI \\ I0.26880/jeki.v3ir.32 \\ Tanggal masuk: 15 Januari 2019 \\ Tanggal ditelaah: 16 Januari 2019 \\ Tanggal diterima: II Februari 2019 \\ Tanggal publikasi: 26 Februari 2019
}

\begin{abstract}
Abstrak Semua orang pasti akan mati. Bagi muslim, mati dalam keadaan Islam adalah tujuan terpenting akhir hidup karena hal itu diperintahkan oleh Allah SWT dalam Al-Quran. Sakaratul maut merupakan saat kritis peralihan dari kehidupan ke kematian. Saat tersebut sangat penting bagi pasien muslim dan keluarganya. Bila pada saat terakhir kehidupan, seseorang mengucapkan kalimat tauhid 'Laailahailallah' maka terbuka peluang masuk surga. Mengucapkan kalimat tauhid saat sakaratul maut bukan hal yang mudah. Untuk itu perlu dibimbing dan dituntun oleh keluarga pasien stadium terminal, suatu upaya yang disebut talkin. Rumah Sakit sebagai penyedia layanan kesehatan paripurna, perlu memberikan fasilitas dan kemudahan kepada pasien stadium terminal dan keluarganya untuk melakukan talkin sesuai kepercayaannya tersebut. Adanya perhatian pihak rumah sakit terhadap hal itu akan meningkatkan kepuasan dan kepercayaan pasien
\end{abstract}

\begin{abstract}
Every human being will face death eventually. For moslems, having that final moment in Islamic faith is the essential purpose as it is mentioned by Allah SWT in Al-Quran. Sakaratul maut or final moment before passing away is the critical moment from life to death for moslem patients and their family. Within that final moment, if a moslem praised Allah SWT with tauhid, 'Laailahaillallah', it is possible for him/her to reach heaven in afterlife. Nevertheless, praise tauhid during that defining moment is difficult. Guidance by family members is compulsory, and the effort is called 'talkin'. Hospital as a provider of comprehensive medical service needs to provide facilities to help families in guiding or performing talkin, to increase trust and satisfaction of patients and families.
\end{abstract}

Masuk rumah sakit baik untuk berobat jalan apalagi untuk rawat inap pada umumnya tidak dikehendaki oleh siapapun. Meskipun semua pasien berkeinginan untuk pulang dalam keadaan sembuh, tetapi tidak ada rumah sakit maupun dokter yang berani memberi jaminan kesembuhan kepada pasiennya. Kalau tidak sembuh berarti pulang dengan meninggalkan gejala sisa (sequelle) atau yang paling tidak dikehendaki dan ditakuti adalah pulang mati. Padahal sudah diketahui bahwa semua orang pasti akan mati. Selanjutnya kajian akan dikupas sesuai dengan agama Islam.
Sepanjang kehidupan manusia di dunia, ada 3 titik penting yang sangat bermakna yaitu kelahiran, pernikahan dan kematian. Yang kedua, tidak semua orang mengalaminya, namun yang pertama dan ketiga semua orang pasti mengalaminya.

QS 03. Ali Imran 185. "Tiap-tiap yang berjiwa akan merasakan mati...."

QS 21. Al-Anbiya 35."Tiap yang berjiwa akan merasakan mati. Kami akan menguji kamu dengan keburukan dan kebaikan sebagai cobaan (yang sebenar-benarnya). Dan hanya kepada Kamilah kamu dikembalikan.”

QS 29. Al-Ankabut 57. "Setiap yang bernyawa akan merasakan mati. Kemudian hanya 
kepada Kami kamu akan dikembalikan."

Kelahiran umumnya disambut dengan senyum, tawa dan rasa bahagia oleh orang di sekitarnya. Sebaliknya kematian biasanya akan mengundang rasa sedih dan tangis bagi yang ditinggalkan. Bagi seorang muslim, kematian merupakan titik yang sangat penting yang akan menentukan nasibnya dalam kehidupan sesudah kematian. Akhir hidup yang baik (husnul khotimah) akan memberinya kesempatan untuk masuk surga, sedang akhir hidup yang buruk (su'ul khotimah) akan menghilangkan kesempatan masuk surga. Islam mewajibkankan seorang manusia dalam keadaan Islam pada saat kematiannya.

QS 03. Ali-Imran 102. "Hai orang-orang yang beriman, bertaqwalah kepada Allah dengan sebenar-benar taqwa kepada-Nya, dan janganlah sekali-kali kamu mati melainkan dalam keadaan beragama Islam." 1

Manusia dapat menemui kematian di mana saja, dengan cara apa saja. Salah satu yang sering menjadi tempat kematian adalah rumah sakit, pada pasien dengan stadium terminal oleh berbagai penyakit. Proses peralihan dari kehidupan ke kematian adalah sakaratul maut, yang menjadi satu titik waktu yang sangat penting bagi seorang muslim.

\section{Pelayanan rumah sakit}

Rumah Sakit adalah tempat memberi pelayanan kesehatan secara perorangan (individual). ${ }^{2} \quad$ Pelayanan perorangan ini membuat bentuk pelayanan yang diberikan bisa berbeda antara satu pasien dengan pasien yang lain (tailor made). Oleh karena itu sumber daya - baik sumber daya manusia (SDM) maupun fasilitas pendukungnya - harus dibekali wawasan dan tingkat perhatian yang memadai dengan pelayanan perorangan tersebut.

Beragam-ragam penyakit memerlukan pula beragam-ragam spesialisasi dokter, perawat, penunjang medis dan lain-lain. perbedaan kelas rumah sakit (A, B, C atau D) dan jenis rumah sakit (umum atau khusus) akan berbeda pula sumber dayanya. ${ }^{3}$ Tetapi ada aspek yang sama di manapun pasien dirawat dan dengan penyakit beragam. Salah satu yang perlu diperhatikan adalah agama dan keyakinan pasien yang memerlukan pelayanan dan perlakukan sama. Setiap pasien memiliki hak untuk didampingi keluarganya dalam keadaan kritis dan menjalankan ibadah sesuai agama dan keyakinan yang dianutnya selama pasien lain tidak terganggu.

Menurut Kode Etik Kedokteran Indonesia dan Sumpah Dokter, ${ }^{4}$ keyakinan pasien harus dihormati, ditaati dan difasilitasi. Ini salah satu hak pasien, yang pada saat-saat kritis, pasien dan keluarganya tentu memiliki intens berkomunikasi dengan Tuhan. Pada umumnya rumah sakit sudah menyediakan fasilitas untuk kebutuhan ibadah, misalnya mushola atau masjid, dan ulama, yang tahu dan mampu melayani jiwa pasien.

Rumah sakit membagi ruang rawat inap sesuai fasilitas ruangnya. Pasien di ruang Very Important Pasien (VIP) boleh ditunggu keluarga di dalam ruang selama 24 jam sehari, dan boleh menerima kunjungan setiap waktu. Mereka yang dirawat di kelas non-VIP, boleh ditunggu keluarganya, meskipun ada perbedaan berapa orang penunggu dibolehkan di antara rumah sakit. Rumah sakit memberi ijin keluarga tinggal di dalam kamar pasien, tetapi ada rumah sakit yang menyediakan tempat terpisah untuk penunggu. Pada prinsipnya pasien dan keluarganya menginginkan kemudahan komunikasi antar mereka, dan pihak rumah sakit berkewajiban memfasilitasinya.

Bila pasien mengalami perburukan keadaan yang dinilai masih reversibel, maka perlu dipindah ke ruang rawat intensif (Intensive Care Unit - ICU) yang peraturannya lebih ketat. Pintu masuk ruang ICU selalu ditutup dan dijaga oleh petugas Satpam (Satuan Pengaman) rumah sakit. Jadwal kunjungan diberlakukan dengan lebih ketat. Pada keadaan seperti ini, timbul perbedaan kepentingan. Keluarga dan pasien lebih kuat keinginannya untuk dekat, di lain pihak dokter dan perawat membutuhkan suasana dan keadaan yang lebih mendukung untuk mengelola pasien dalam keadaan kritis, misalnya untuk mencegah infeksi nosokomial karena sebagian kasus yang dirawat dipandang sebagai populasi pasien yang rentan mengalami infeksi nosokomial tersebut. Selain itu sebagai ruangan tempat merawat pasien dengan penyakit kritis, membutuhkan suasana yang 
lapang, sehingga jika terjadi kegawatan maka kelapangan ruang dapat memadai bagi staf medis untuk melakukan pertolongan. Pada keadaan demikian, perlu komunikasi dua arah yang baik antara dokter dengan keluarga pasien. Bila keluarga diberi penjelasan yang adekuat, pada umumnya keluarga akan mengerti dan mematuhi peraturan rumah sakit.

\section{Alasan Keluarga Ingin Bersama Pasien Saat Kritis}

"Sesungguhnya Allah masih menerima taubat seseorang selagi belum terdengar dengkurnya (menjelang mati)."(HR. AtTirmidzi). ${ }^{3}$ Maksudnya, nyawanya belum sampai tenggorok, saat orang itu melihat kesudahan hidupnya, apakah mendapat rahmat atau kehinaan. Hal ini yang perlu diketahui oleh semua pihak yang terlibat pelayanan rumah sakit. Pasien dan keluarganya menginginkan pulang dari rumah sakit dalam keadaan sembuh dengan kualitas hidup kembali seperti semula. Namun seberapapun majunya ilmu kedokteran dan para dokternya, serta seberapapun lengkap dan baiknya fasilitas suatu rumah sakit, semua ada keterbatasannya. Tidak terhindarkan pasti ada pasien yang meninggal di rumah sakit. Bagi umat Islam semua berkeinginan wafat dalam keadaan Islam. Kebutuhan menjalankan syariat agama di akhir kehidupan seorang pasien perlu dipahami oleh pengelola rumah sakit, sehingga dapat memberikan fasilitas yang memadai.

\section{Sakaratul Maut}

Mati dalam keadaan Islam sangat diinginkan oleh semua Muslim. Kualitas keimanan ditentukan oleh bagaimana seseorang saat meninggal. Kesempatan terakhir menjelang kematian, masih ada satu peluang emas yang bisa menjamin seseorang bisa diterima Allah di surga. "Tuntunlah orang yang hendak meninggal dunia di antara kalian supaya mengucapkan kalimat La ilaha illalah" (HR Muslim). ${ }^{1}$ Kalimat laa ilaaha illalahu (kalimat tauhid) adalah kunci kebahagiaan abadi bagi seseorang yang sedang mengalami sakaratul maut. Nabi Muhammad SAW bersabda: "Tidaklah ucapan itu, kecuali pasti masuk surga" (HR. Al-Bukhari). ${ }^{1}$

$$
\text { Allah SWT berfirman kepada nabi }
$$

Musa: "Wahai Musa, seandainya langit yang tujuh serta seluruh penghuninya, selain Aku, dan ketujuh bumi diletakkan dalam satu sisi timbangan, niscaya kalimat laa ilaaha illallah lebih berat timbangannya. (HR Ibnu Hibban dan Al-Hakim) ${ }^{1}$

Pasien dalam keadaan sakaratul maut perlu dituntun untuk mengucapkan kalimat tauhid, yang disebut talkin. ${ }^{5}$ Talkin adalah proses/upaya mengingatkan kepada seeorang yang sedang menghadapi sakaratul maut, untuk mengucapkan laa ilaaha illallah (cukup satu kali) menjelang dicabutnya nyawa. Temuantemuan neuroscience telah membuktikan bahwa pasien yang sudah berada di stadium terminal, bahkan pasien yang sudah hilang kesadarannya dapat dirangsang melalui stimulus suara dari luar. Dalam keadaan medis tertentu, beberapa jalur kesadaran dan beberapa bagian otak masih utuh dan masih memiliki beberapa fungsi, di antaranya menangkap stimulasi suara. ${ }^{6}$ Keadaan itu antara lain saat hilang kesadaran, selama anestesi umum dan stadium terminal, hingga terapi paliatif. Pada keadaan demikian, stimulasi pendengaran dengan talkin dapat dilakukan. Salah satu anggota keluarga membisikkan kalimat tauhid ke telinga pasien secara berulang, sampai terdengar pasien mengucapkannya. Waktu yang dibutuhkan sangat bervariasi, beberapa menit sampai mungkin lebih dari satu jam. Kalau sudah diucapkan, maka tugas keluarga sudah selesai, dan berdoa untuk mengiringi kematian saudaranya.

Menurut Prawiroharjo P, talkin sebaiknya difasilitasi pada beberapa situasi klinis sebagai berikut: $^{7}$

1. Hilang kesadaran, yang dibuktikan dengan tidak adanya respons stimulus visual, verbal dan stimulus nyeri. Hilang kesadaran bisa akibat lesi intrakranial atau oleh gangguan metabolisme atau akibat keadaan toksik.

2. Emergensi kode biru. Wawasan medis Emergensi Kode Biru perlu meliputi sampai ke akhir kehidupan. Bagi dokter dan tenaga kesehatan muslim pelayanan emergensi tidak cukup hanya aspek medis saja, tetapi juga harus mencakup aspek spiritual dan agama pasien. Layanan talkin merupakan respons rumah sakit yang dilakukan dalam 
mengamankan kehidupan spiritual pasien. Oleh karena itu talkin perlu dimasukkan ke dalam standar prosedur operasional Emergensi Kode Biru.

3. Zona merah di Instalasi/UnitGawatDarurat. Layanan emergensi dapat dibagi menjadi tiga warna zona: hijau, kuning, dan merah. Zona hijau diperuntukkan bagi pasien yang memiliki emergensi paling ringan dan tidak mendesaknya. Zona merah bagi yang pasien dengan keadaan yang mengancam kehidupan sehingga memerlukan observasi dan intervensi intensif. Sedangkan zona kuning, bagi pasien yang keadaannya berada di antara pasien yang di zona hijau dan zona merah. Layanan talkin perlu diberikan kepada pasien dalam zona merah.

4. Selama anestesi umum. Pasien dalam anestesi umum perlu untuk ditalkin karena selama dalam anestesi umum pasien tidak bisa beribadah. Penelitian membuktikan bahwa pasien dalam anestesi umum dapat mendengar dan mampu memberikan respons kognitif jika stimulasi dilakukan berulang-ulang, meskipun tidak memberikan respons verbal.

5. Akhir hidup pada perawatan paliatif. Di beberapa negara, perawatan paliatif pada akhir hidup pasien dilakukan di nursing home atau home care yang ditunjang oleh kunjungan dan koordinasi dengan tim medis. Negara lain menyelenggarakan pelayanan $\mathrm{di}$ rumah sakit karena keterbatasan sumber daya untuk melakukan di luar rumah sakit. Talkin perlu dimasukkan ke dalam protokol pelayanan ini.

\section{Kewajiban Rumah Sakit}

Dokter dan perawat memiliki kewajiban memantau perjalanan penyakit pasien. Untuk pasien di ruang rawat inap, biasanya keluarga dapat mengetahui kondisi terminal atau perburukan kondisi pasien ke arah terminal, dan biasanya keluarga pasien melaporkan kondisi tersebut ke perawat atau tim jaga. Bagi mereka yang di rawat di ruang ICU menjadi kewajiban dokter dan perawat memberi informasi kepada keluarga, saat masuk fase terminal.

UU Nomor 44 Tahun 2009 tentang Rumah
Sakit pasal 32 ayat (1) menyatakan bahwa setiap pasien mempunyai hak didampingi keluarganya dalam keadaan kritis; pada ayat (m) dikatakan bahwa pasien mempunyai hak menjalankan ibadah sesuai agama atau kepercayaannya yang dianutnya selama hal itu tidak mengganggu pasien lainnya.Sesuai dengan UU No 44 tahun 2009 pasal 29, menjadi kewajiban rumah sakit untuk memberi informasi kepada keluarga pasien bila keadaan pasien sudah masuk ke stadium terminal dan memberi kesempatan dan mengatur ruang untuk pelayanan akhir hidup. ${ }^{8}$

Dalam menyikapi adanya kebutuhan tersebut rumah sakit dengan persetujuan keluarga pasien dapat memberi kebijakan sebagai berikut :

1. Pasien tetap berada di tempat perawatannya, cukup disediakan satu kursi untuk satu orang anggota keluarga secara bergantian menuntun talkin.

2. Jika keadaan memungkinkan dan ada fasilitas, pasien dipindahkan ke ruang terpisah.

3. Kadang keluarga pasien ingin membawa pulang pasien yang dalam keadaan kritis. Mereka menginginkan pasien meninggal di rumah. Masalah muncul jika pasien masih menggunakan peralatan medis yang tidak dapat diberikan di rumah. Dalam keadaan demikian, perlu dibicarakan dengan keluarga pasien.

Upaya menuntun talkin ini bisa berlangsung dalam beberapa menit, tetapi bisa juga lebih dari satu jam. Proses selesai setelah pasien mengucapkan kalimat tauhid satu kali. Sesudah itu anggota keluarga tetap menunggu sambil berdoa, dan menyaksikan pasien meninggal serta menerima kepastian dari dokter tentang meninggalnya pasien.

Proses ini merupakan titik kulminasi tertinggi kepuasan keluarga pasien yang meninggal. Artinya keluarga telah berhasil menutup hidup saudaranya dengan penutup kalimat tauhid, yang merupakan jaminan diterimanya yang meninggal masuk surga. Bagi rumah sakit, pemberian fasilitas saat stadium terminal pasien, menjadi bahan pemasaran positif bagi masyarakat muslim. Selanjutnya keluarga pasien mengikuti peraturan rumah 
sakit bagaimana jenazah bisa dibawa pulang.

\section{KESIMPULAN}

Talkin merupakan prosedur menuntun kematian umat Islam. Dengan berhasilnya seorang muslim mengucapkan kalimat tauhid sebelum roh dicabut, maka ini merupakan jaminan dia masuk surga. Oleh karena itu rumah sakit perlu mengetahui kapan talkin harus dilakukan dan memberikan kesempatan dan fasilitas kepada pasien dan keluarga untuk melakukannya. Rumah sakit dan fasilitas layanan kesehatan lainnya perlu lebih memperhatikan hak pasien dan keluarganya yang muslim ini dalam bentuk memfasilitasi sebaik mungkin keluarga pasien menjalankan kepercayaannya sebagaimana tuntunan syariat Islam, yaitu dengan membimbing talkin kepada pasien muslim terminal hingga akhir hayatnya.

\section{KONFLIK KEPENTINGAN}

Tidak ada konflik kepentingan

\section{REFERENSI}

1. Tim Disbintalad, editor. Al Qur'an terjemah Indonesia. Jakarta: Sari Agung; 2005.

2. Peraturan Menteri Kesehatan Republik Indonesia Nomor 56 Tahun 2014 tentang Klasifikasi dan Perizinan Rumah Sakit. 2014.

3. Al-Qurthubi IS. At-Tadzkirah: Bekal menghadapi kehidupan abadi. Jakarta: Pustaka Al-Kautsar; 2017.

4. Majelis Kehormatan Etik Kedokteran Indonesia. Kode etik kedokteran tahun 2012. Jakarta; 2012.

5. Al-Jaza'iri SABJ. Minhajul Muslim: Konsep hidup ideal dalam Islam. Jakarta: Darul Haq; 2017.

6. Koch C, Massimini M, Boly M, Tononi G. Neural correlates of consciousness: Progress and problems. Nat Rev Neurosci. 2016 May 1;17(5):307-21. https://doi.org/10.1038/ nrn.2016.22.

7. Prawiroharjo P. Practice of talqeen: Starting, terminating, and hospital policy advocacies for muslim patients in hospital. Dalam: FIMA Year Book 2016: Encyclopedia of Islamic medical ethics - part III. Amman: Jordan Society for Islamic Medical Sciences; 2017.

8. Undang-Undang Republik Indonesia Nomor 44 Tahun 2009 tentang Rumah Sakit. 2009. 